\title{
Enlightenment of American Legal Theory and Practice of "Piercing the Corporate Veil" to China
}

\author{
Minghao $\mathrm{Li}^{1}$ \\ ${ }^{1}$ School of Law, University of Illinois at Urbana-Champaign, Illinois, USA \\ Correspondence: Room 802, $1^{\text {st }}$ Unit, 7 Building, Gaotie Jiayuan, Songhuajiang Street, Nangang District, Harbin, \\ Heilongjiang Province, China. Tel: 86-151-2106-8607. E-mail: liminghaomarilyn@163.com
}

Received: July 2, 2021

doi:10.5539/jpl.v14n4p80
Accepted: July 29, $2021 \quad$ Online Published: July 30, 2021

URL: https://doi.org/10.5539/jpl.v14n4p80

\begin{abstract}
Observing the current legal system and theory of America, "piercing the corporate veil" is in a state of "chaos" in both of them. How can China learn from the rule of law and the theory of "piercing the corporate veil"? How to avoid its harm and gain its benefits? Due to different national conditions and judicial systems, also differences between civil law system and common law system, and at the same time, the world is in the era of globalization, the exchange of legal culture of Chinese legal system is expanding and deepening day by day. Therefore, it is necessary to study the rule and theory of "piercing the corporate veil". This paper systematically summarizes the current situation of the rule and theory of "piercing the corporate veil" in America, explores the causes of the confusion, and puts forward some suggestions to prevent the occurrence of problems in China after transplanting this rule, which is very necessary and timely.
\end{abstract}

Keywords: pierce the corporate veil, disregard of corporate personality, theory and principle, institutional comparison

\section{Introduction}

At the end of the 19th century, the number of American companies increased rapidly, resulting in the phenomenon of intermingled good and bad; The company scale expanded unceasingly, producing the monopoly market phenomenon; The abuse of the company's independent personality and the limited liability of shareholders are prominent, while the law can do nothing about it. All these seriously endanger the rapid development of the American economy. As a way to solve the problem, American courts created the rule of piercing the corporate veil. The company's independent liability is the veil in front of the shareholders, which makes the shareholders bear limited liability; When the shareholders abuse the company's independent personality to evade legal or contractual obligations, they should pierce the company's veil and investigate the shareholders' responsibility.

In 1993, the Companies Act in China established the form of companies and limited liability system, formulated a series of strict rules for capital raising and maintenance, and set a minimum capital threshold, which turned away some investors or entrepreneurs, hindered the establishment of new companies and inhibited economic development. This act does not provide for the subsequent relief of creditors. In order to encourage and stimulate investment, the Companies Act of 2005 was amended to abolish the minimum capital threshold. This rule is beneficial to shareholders, requires legislators to balance the protection of creditors, and finally turns to the ex post protection of piercing the corporate veil as an alternative remedy. In this amending version, "piercing the corporate veil" was institutionalized as "disregard of corporate personality".

In the U.S., "piercing the corporate veil" is in a state of "chaos" both in theory and institution. The analysis of this issue by American scholars does not dispel doubts about the "chaos" of piercing the corporate veil. On the contrary, it complicates the understanding of this rule. Many scholars hold different opinions and only see what they want to see, which makes alert whether China will repeat the same mistakes after transplanting this rule? Therefore, this paper aims to sort out the theoretical and institutional confusion of piercing corporate veils in America, explore the causes of the confusion, and summarize possible solutions and methods of American scholars to this chaotic situation, so as to warn China of the existing situation and problems after transplanting this rule, and then provide suggestions on the limits and methods of use. The first part describes the definition of piercing the corporate veil, the status quo of confusion and the reasons, and sorts out solutions and methods proposed by American scholars; 
The second part expounds the current situation and problems after transplanting this rule in China, and provides suggestions for China to learn from the legal theory and practice of "piercing the corporate veil" in America.

\section{The Definition, Confusion, Causes and Solutions of Piercing the Corporate Veil in America}

\subsection{The Definition of Piercing the Corporate Veil}

After the American economic crisis in 1873, most enterprises operated in the form of companies. At the end of the 19th century, the number of companies increased sharply and the scale of companies expanded, resulting in the problems of good and bad companies and monopolizing the market, which seriously harmed the development of the American market economy. For this reason, the American court created the system of "piercing the corporate veil".

"Piercing the corporate veil" was founded in the case of the U.S. v. Milwaukee Refrigerators Transit Co. (1905) ${ }^{1}$ In this case, the court clearly stated that unless there were sufficient reasons for objection, the corporate personality was recognized in principle. However, if a legal person is used to undermine public interests, or to legitimize lawlessness, or to safeguard fraud, or to protect crime, the law will regard the company as a combination of several people.

It can be seen from the above cases that in principle, the company and shareholders are recognized as different subjects in American company law, but the principle of limited liability of shareholders is not absolute. Piercing the corporate veil as a means of equitable relief created by justice is a denial of the principle of limited liability. In order to prevent the abuse of limited liability and maintain social justice, the law should deny limited liability in some cases, allow the company's creditors to claim compensation directly from the shareholders, and let the shareholders bear unlimited liability.

\subsection{Chaotic Situation}

\subsubsection{The Theoretical Confusion of "Piercing the Corporate Veil" in America}

The traditional theory acquiesces in the scope of limited liability and regards piercing the veil as an exception of limited liability. The method of analyzing limited liability provides a blueprint for Robert Thompson's pioneering research. This method divides the cases of piercing the veil into four categories: contract, criminal, law and tort.

Robert Thompson's empirical research shows that there is a huge gap between theory and practice on piercing the veil. In theory, most scholars believe that due to creditors being unable to bargain or reduce their own risks in the tort relationship, piercing the veil is more likely to deny the independent personality of the company in tort than in contract cases; Thompson analyzed nearly 1600 cases of piercing the veil from federal or state courts, and found that piercing the veil is more common and popular in contractual than in tort relationship. (Thompson, 1991) Another reason for concern is insufficient capital. Scholars and judges have been discussing how to measure the evidence of insufficient capital. Theoretically, capital inadequacy seems to affect moral hazard more directly, so it is more relevant in tort; But Thompson's research results show that in tort, the element of insufficient capital only appears in a small number of cases of piercing the veil. As a result, the predictive value of capital shortage is still unclear.

Thompson's research has a wide range of influences, but the anti-legal intuition of his research results does complicate the academic understanding of piercing the corporate veil. The asymmetric result that he finds that piercing the corporate veil system is more dominant in the contractual relationship than in the tort relationship has become one of the most common sense riddles in corporation law.

Most of the follow-up studies on piercing the veil are based on Thompson's research to draw lessons from or to criticize, trying to explain the results of his anti-legal intuition. One of the scholars has summarized the experience and lessons of Thompson's research, took 2908 cases from 1658 to 2006 as the data set, expanded the collection scope of piercing veil cases, and conducted a new round of empirical research, presenting the most comprehensive mechanism and principle behind piercing the veil so far. (Oh, 2013) A new round of empirical research results have confirmed the legal intuition of scholars on piercing the veil to a great extent, but whether his research results will be widely accepted as Thompson's research needs time to test. (Oh, 2013)

Some scholars even overturn the theoretical premise of piercing the corporate veil and propose that piercing the veil is divorced from the traditional loss distribution analysis. Piercing the veil has nothing to do with corporate responsibility, of which the balance of incidental investigation involving relief should be independent of the theory of loss allocation. (Oh, 2013) This conclusion completely subverts the traditional analysis of the basis of piercing

\footnotetext{
${ }^{1}$ Sanborn J., U.S. v. Milwnakee Refrigerator Transit Co. 142 F.2d 247,255 (C.C.E.D.Wis 1905)
} 
the veil, and adds the information dimension of analyzing this rule in theory. The most intuitive feeling to me is that the fog is formed because of too much information, which makes it difficult for us to see clearly the truth of piercing the corporate veil.

\subsubsection{The Practical Confusion of "Piercing the Corporate Veil" in America}

There is no uniform tendentious standard for piercing the corporate veil in America. In practice, the most common standard of piercing the corporate veil requires the plaintiff to prove that: (a) the shareholder and the company are "one", and the company is the "other self" or "pure tool" of the shareholder, so as to prove that the shareholder completely controls and dominates the company, making the fraud, error or injustice permanent. (b) If the shareholder does not bear the responsibility, it will lead to unfair results and cause unfair losses or injuries to the plaintiff. (Klein, 2010) However, this common standard itself is still ambiguous: when testing the "one body" elements of the company and shareholders, the court only examines the formal elements such as "not complying with the company's procedures, mixed personal and company property, no separate office", and ignores the substantive elements; When reviewing the element of "unfair result", the court does not specify the object of review. ${ }^{2}$

A more uncertain benchmark is for the court to judge whether it will lead to unfair results by examining whether the capital of the company at the time of establishment is insufficient to repay the foreseeable debts. (Tan, Wang \& Hofmann, 2019) In 1986, the West Virginia Supreme Court of appeal summarized 19 factors that each court considered when piercing the corporate veil. ${ }^{3}$ The listing of these factors only has reference value, it has no practical significance for specific judgments.

In Lowendah $1^{4}$,the court outlines a standard different from the most common one described above. First, it requires more than just control of corporate entities. The liability for compensation must depend on "the complete control over the attacked transaction, not only financial control, but also complete control over the policies and commercial practices, so that the legal entity related to the transaction does not have its own thoughts, will or existence at that time." Second, the defendant must take advantage of this control to "commit fraud or wrong conduct, commit dishonest and unfair conduct in violation of statutory or other positive legal obligations, or violate the legitimate rights of the plaintiff." Finally, control and breach of duty must result in the claimed injury or loss. This standard only provides reference for the specific judgment of subsequent cases.

Through reading nearly 50 cases of piercing the veil in America, I conclude that America has adopted a relatively free approach to piercing the veil in practice. In the Gorrell case ${ }^{5}$, the real basis for piercing the corporate veil is that the corporate governance is extremely bad in the court's view. Because it fails to fully distinguish the activities of the company from those of its parent company/owner, the court pierces the corporate veil. In the Sabine Towing case $^{6}$, the court regards breach of contract as one aspect of the wrongful act. The Parker case ${ }^{7}$ shows that there is a broader interpretation of wrongdoing in the U.S. In this case, the court maximizes limited liability and regards the establishment of a company as an illegal act in order to limit the behavior that may be liable in the future. When it damages the public interest, it almost does not bear the responsibility for the damage, which constitutes the abuse of privilege and pierces the veil of the company.

The above cases all involve parent subsidiary relationships. Perhaps this can explain America's freer practice of piercing the veil. In the context of enterprise groups, the theoretical analysis of limited liability becomes irrelevant to a large extent. Any act of piercing the veil within the group company will not affect the ultimate investors of the enterprise, because it usually does not extend beyond the parent company. This practice reflects the limitations behind the doctrine of limited liability, which makes piercing the corporate veil, a rule without tendentious standards, more and more "arbitrary" in practice.

To sum up, the practice of piercing the corporate veil in America can be described as "chaos", and the general criteria for piercing the veil on what occasions and under what conditions are the problems to be solved in America so far. In view of the diversity of judicial methods, the use of expansionary speech and a large number of legal opinions, the veiled cases in America lack the certainty and predictability required by modern commerce. Piercing

\footnotetext{
${ }^{2}$ An example is the divestiture of basic assets from the company by shareholders through dividends, high salaries or other remuneration for services.

${ }^{3}$ Laya v. Erin Homes, Inc., 352 S.E.2d 93, at 98-99

${ }^{4}$ Lowendahl v. Baltimore \& O. R. Co., 287 N.Y.S. 62,76 (N.Y. App. Div.), aff'd 6 N.E.2d 56 (N.Y. 1936).

${ }^{5}$ Gorill v. Icelandair/Flugleider, 761 F.2d 847, 853 (2d Cir. 1985).

${ }^{6}$ Sabine Towing \& Transportation Co, 575 F.Supp. at 1448.

${ }^{7}$ Parker v. Bell Asbestos Mines, Ltd, 607 F. Supp. 1397 (E.D. Pa. 1985).
} 
the veil in tort and contract still has high discretion and serious problems for enterprise planners. (Macey \& Mitts, 2014)

\subsection{The Causes of the Confusion of "Piercing the Corporate Veil" in America}

There are many reasons for the confusion of piercing the Veil: first, the practical standard of piercing the veil is very complex. Although the court has compiled a detailed list of ex post facto specific elements, there is no necessary and feasible connection between these elements and potential hazards. Second, in piercing the veil, judges use too many metaphors in practice, which also leads to the confusion of piercing the veil. Piercing the corporate veil is also called "the law of metaphors". (Blumberg, 1983) The inherent inaccuracy of metaphors leads to the confusion of piercing the veil. Finally, in the practice of piercing the veil, judges regard these standards as rules throughout the whole process, no matter in contract, tort, tax, bankruptcy and other occasions, resulting in the incompatibility between piercing the veil and legal policies in different fields, thus increasing the confusion of this rule.

Piercing the veil has been denounced as a rule of "rationally disturbing" and "incoherence" (Millon, 2007), and its "fuzziness and randomness" 8 similar to "lightning, because it is rare, serious and unprincipled."(Easterbrook and Fischer, 1985) Therefore, rectification of the name of piercing the veil is described as "futile practice: trying to clarify a field standard, which is often characterized by ambiguity, unpredictability, and even a certain degree of surface randomness."(Bainbridge, 2001) This prompts some scholars to call for the complete abandonment of this rule.

\subsection{Solutions and Methods Proposed by American Scholars}

Facing the confusion of piercing the veil, American scholars take different solutions: (a) Improve it and rectify its name; (b) Abolish this rule and use other alternatives.

Scholars who advocate subsisting on piercing the veil believe that it is not the fault of the rule itself, but the problem of its interpretation and study. This rule has positive significance for promoting social justice and economic efficiency through the improvement and innovation of the theoretical analysis framework. Therefore, some scholars have established a new theoretical framework, and believe that piercing the veil is to achieve three public policy goals, and each goal is consistent with economic efficiency: (a) to achieve the purpose of existing laws and regulations; (b) to prevent shareholders from obtaining credit through misrepresentation; (c) to enhance the value of bankruptcy and realize the orderly and effective disposal of bankruptcy property. This three-part classification provides specific and logical reasons for piercing the corporate veil. For this theory, the most effective way is not to abandon the practice of piercing the veil, but to let the judges determine whether piercing the veil in a specific case can achieve one of the three public policy objectives mentioned above. (Macey and Mitts, 2014)

However, scholars who advocate abolishing piercing the corporate veil believe that this rule is unreasonable, and its standard is vague, leaving a lot of discretion for judges; The result is uncertain and lack of predictability, which increases the transaction cost for small enterprises; At the same time, there is no evidence that piercing the veil is strictly applied to produce beneficial policy effects. Judges are usually more concerned with the facts and fairness of specific cases than the impact of individual shareholder responsibility on the whole society. Therefore, piercing the veil has social costs, but no social benefits. Because of the rarity and non-institutionalization of the piercing the veil, we should abolish it and apply other alternatives. (Bainbridge, 2001)

As for other solutions to replace piercing the corporate veil, some scholars put forward the rule of direct liability (that is, whether the defendant shareholder does anything he/she should bear personal responsibility). For example, shareholders can (and should) take personal responsibility when shareholders' fraud results in creditors abandoning the contract protection. Similarly, if shareholders take advantage of fraudulent transfer or insider to withdraw capital from the company and make it insufficient afterwards, direct personal responsibility will be the appropriate solution. (Bainbridge, 2001)

Some scholars put forward constructive trust, and hole that constructive trust is suitable for the typical scene of piercing the veil in structure. Different from the traditional loss allocation analysis, which will screen different types of creditors/claims, companies and shareholders to determine when exceptions should be made, while constructive trust will treat all these variables as given. By paying attention to whether the company's failure to perform the judgment will lead to the unreasonable distribution of interests, constructive trust completely avoids the trap of justifying the relief by resorting to the attribute of original creditor's rights. Moreover, the investigation

${ }^{8}$ Allied Capital Corp. v. GC-Sun Holdings, 910 A.2d 1020, 1042 (Del. Ch. 2006). 
is flexible enough to accommodate any transfer of interest by the company to shareholders. From the perspective of ownership, constructive trust represents a pre-bankruptcy claim on the misappropriated asset, which must be owned by its current legal owner. Similarly, from the perspective of relative rights, its role is to protect the priority claims owned by the plaintiff and beneficiary from bankruptcy. In addition, from the perspective of corrective justice, it deprives ordinary non-secured creditors of the ability to unjustly benefit from assets that could not have been distributed. (Oh, 2013)

\section{How China Learns from the Legal Theory and Practice of "Piercing the Corporate Veil"}

The core of the confusion of piercing the corporate veil in America lies in the ambiguity of its standards and the uncertainty and lack of predictability of its results. In order to avoid repeating the "confusion" of this rule, China should consider the uniform standard as the judicial practice of judges when uses it for reference. In the context of COVID-19, the epidemic leads to social isolation, social isolation leads to automation demand, and demand upgrading leads to hitherto unknown technology innovation. On a global scale, technological progress will prompt thousands of small and micro enterprises to burst forth; In China, the emergence of new technologies, the use of the Internet, the development of new energy and new materials provide a new space for entrepreneurs. In the future, there will be a large number of entrepreneurs in China, whose needs will promote the development of entrepreneurial space. Therefore, we should grasp the current epidemic situation of economic recovery and mass entrepreneurship, apply the rule prudently, and avoid restricting economic recovery and people's entrepreneurial enthusiasm under the judicial applicability of the determinate standard.

\subsection{The Status Quo of "Disregard of Corporate Personality” in China}

The Companies Act was revised in 2005, which introduces piercing the corporate veil and institutionalizes it into the rule of disregard of corporate personality in Article 20. China explicitly stipulates the rule of disregard of corporate personality, but it is too simple and rough, which has caused great confusion in the judicial practice. The original intention of legislators is to use the rule of disregard of corporate personality in a limited way, but in practice, this rule has been exaggerated in many cases. The piercing rate of corporate veils in China is significantly higher than that in other countries. In a five-year study, $63.64 \%$ of veil-piercing success rate in China is significantly higher than that in major common law countries. (Huang, 2012) Chinese courts show "judicial activism" in cases of denial of corporate personality, and judges are "enthusiastic" about denying independent personality of companies.

So in 2019, in view of the rule of disregard of corporate personality, China has made specific provisions on the subject elements, behavior elements, result elements and common situations. It emphasizes that when hearing a case, we need to make a comprehensive judgment according to the facts of the case, which is not only prudent but also applicable.

\subsection{Problems of "Disregard of Corporate Personality" in China}

At the level of legislation, the rule of disregard of corporate personality, as a transplant rule, has no legal history in China. Driven by urgent economic development, disregard of corporate personality was clearly stipulated in 2005, which means that this rule cannot be mature enough in legislative technology. The current Companies Act of China has only systematic provisions in legislation, and lacks specific applicable detailed provisions, which directly leads to a lack of operability. The No.15 guiding case of disregard of corporate personality in China is only aimed at the situation of affiliated companies, which is still not comprehensive enough. Although China reiterated the principle of "cautious use" applicable to the disregard of corporate personality rule in 2019, did not give specific instructions and circumstances on how to "cautious use". In addition, disregard of corporate personality lacks supporting provisions on the protection of social public interests, national interests and creditors.

At the level of judicial procedure, the rule of disregard of corporate personality has no clear and specific provisions on the burden of proof. Except for one person company, the burden of proof can only be applied to the basic rule of "who claims, who provides evidence" in the civil procedure law. This makes it difficult for the relatively weak infringee to bear the burden of proof. Because of information asymmetry and unequal status in business activities between the company and its creditors, it is impossible for creditors to understand the internal operation, management, internal decision-making and other information of the company. It is the creditor who bears the burden of proof, which makes it impossible for the creditor to defend his/her rights on the grounds that the shareholders abuse their rights. 


\subsection{The Perfection of "Disregard of Corporate Personality" in China}

\subsubsection{Improvements at Legislative Level}

As for the principle of "applying prudently and using when applicable" put forward in 2019, I suggest that it can be distinguished according to the lines of business: for companies with actual products or services, such as manufacturing companies, it should be cautious when applying the rule of disregard of corporate personality. Such companies' own technology, equipment and products can be used to repay their debts, without the need to pierce the veil to relieve creditors. For companies that have no actual products or services, such as shell companies, disregard of corporate personality should be applied. Intermediary, insurance, consulting, foreign trade, Internet content services, telecommunications services and other industries are prone to such non-entity companies. The rule of disregard of corporate personality should be different from entity companies in application. We should distinguish the industries of the company, specify the application of the principle of "cautious use", and further improve the disregard of corporate personality in legislation.

Aforementioned suggestions can be improved by legislation or judicial interpretation. The theory of piecing the corporate veil (disregard of corporate personality in China) comes from western countries. Due to different legal systems, the rule of disregard of corporate personality should respect the fact that it is not suitable to be too rigid and dogmatic in legislation, which is also the result of considering the characteristics of equity. Therefore, we can introduce supporting legislation and judicial interpretation as an important supplement to the law, give play to the role of interpretation in legal practice, and also have guiding significance for case judgment.

\subsubsection{Improvements at Procedural Level}

On the issue of burden of proof, we should make clear and specific provisions on distribution. In western countries, the difficulty of proof of creditors is fully considered in the distribution of burden of proof. Whether the case infringes the interests of creditors due to the abuse of shareholders' rights should be proved by creditors, and the burden of proof for the remaining part should be proved by the defendant to prove that he/she has not abused the independent personality of the company. In this way, the imbalance of burden of proof between the plaintiff and the defendant due to the social status and information asymmetry can be effectively solved.

\section{Conclusion}

America is more free to pierce the corporate veil. Similarly, the court has adopted a looser approach to the disregard of corporate personality in China. There is no simple, systematic and feasible standard for "piercing the corporate veil" in America. In China, legislators also use abstract description to stipulate the rule of disregard of corporate personality, leaving judicial practitioners with greater discretion. The abuse of disregard of corporate personality will endanger corporate institutions, shake the principle of limited liability of shareholders, and inhibit the enthusiasm of the public to invest and create new companies. This will conflict with the overall economic background that China encourages all people to start businesses and stimulates economic recovery in this special epidemic period. As for the disregard of corporate personality, it should be applied prudently in the current economic environment. In legislation, it should refine the provisions of this rule, clarify the specific concept and situation, and let the judicial practitioners have instructions to follow in the specific judgment; In the procedure, the distribution of the burden of proof should be determined, and the substantive rule should be escorted by the specific and clear procedure.

\section{Acknowledgments}

This article is completed under the guidance of Mr. Ansheng Huang. He gave advice on the overall structure and writing ideas of this article, and drafted a summary for me after reading through the whole paper. I would like to extend my most sincere and heartfelt thanks to Mr. Ansheng Huang!

In addition, the successful completion of this article is inseparable from my mother's help. In the subsequent revision of the paper and the consideration of words and sentences, my mother provided suggestions and guidance, which helped me overcome difficulties. Thank you very much! I love you!

\section{References}

Bainbridge, S. M. (2001). Abolishing Veil Piercing. 26 lowa J. Corp., L. 479, 507. https://dx.doi.org/10.2139/ssrn.236967

Blumberg, P. I. (1983). The law of corporate groups: Procedural problems in the law of parent and subsidiary corporations (1st ed., § 1.02, 8). Little Brown \& Co Law \& Business.

Easterbrook, F. H., \& Fischel, D. R. (1985). Limited Liability and the Corporation. 52 U. CHI. L. REV., 89, 89. https://doi.org/10.2307/1599572 
Huang, H. (2012). Piercing the Corporate Veil in China: Where Is It Now and Where Is It Heading? $60 A M . J$. COMP. L., 743, 744. https://doi.org/10.5131/AJCL.2012.0004

Klein, W. A. (2010). Business organization and finance: Legal and economic principles (11th ed., 148). Foundation Press.

Macey, J., \& Mitts, J. (2014). Finding Order in the Morass: The Three Real Justifications for Piercing the Corporate Veil. 100 Cornell L. Rev., 99. https://dx.doi.org/10.2139/ssrn.2398033

Millon, D. (2007). Piercing the Corporate Veil, Financial Responsibility, and the Limits of Limited Liability. 56 EMORY L.J., 1305, 1381. https://dx.doi.org/10.2139/ssrn.451520

Oh, P. B. (2013). Veil-Piercing Unbound. 93 B.U.L. Rev., 89. http://dx.doi.org/10.2139/ssrn.1925009

Tan, C. H., \& Wang, J. Y., \& Hofmann, C. (2019). Piercing the Corporate Veil: Historical, Theoretical and Comparative Perspectives. 16 Berkeley Bus. L.J., 140. https://dx.doi.org/10.2139/ssrn.3254130

Thompson, R. B. (1991). Piercing the Corporate Veil: An Empirical Study. 76 CORNELL L. REV., $1036,1044$. Retrieved from http://scholarship.law.cornell.edu/clr/vol76/iss5/2

\section{Copyrights}

Copyright for this article is retained by the author(s), with first publication rights granted to the journal.

This is an open-access article distributed under the terms and conditions of the Creative Commons Attribution license (http://creativecommons.org/licenses/by/4.0/). 